\title{
Microenxertia interespecífica ex vitro em maracujazeiros
}

\author{
Wilson Vicente Souza Pereira ${ }^{(1)}$, Leonardo Monteiro Ribeiro(2), Lorena Melo Vieira(3) \\ e Maria Olívia Mercadante-Simões ${ }^{(2)}$
}

\begin{abstract}
(1)Universidade Federal de Lavras, Departamento de Ciência Florestal, Campus Universitário, CEP 37200-000 Lavras, MG. E-mail: wvicentesp@yahoo.com.br (2)Universidade Estadual de Montes Claros, Departamento de Biologia Geral, Avenida Ruy Braga, s/no, CEP $39400-000$ Montes Claros, MG. E-mail: leomrib@hotmail.com, omercadante@hotmail.com ${ }^{(3)}$ Universidade Federal de Viçosa, Departamento de Biologia Vegetal, Avenida P.H. Rolfs, s/no, CEP 36570-000 Viçosa, MG. E-mail: Imelovieira@hotmail.com
\end{abstract}

\begin{abstract}
Resumo - Este trabalho teve como objetivo avaliar o efeito da espécie de Passiflora usada como porta-enxerto no pegamento e desenvolvimento da microenxertia interespecífica ex vitro e caracterizar anatomicamente a região em que ela é realizada. Ápices caulinares de Passiflora edulis f. flavicarpa foram enxertados em hipocótilo de porta-enxertos de $P$. alata, $P$. cincinnata, $P$. edulis e $P$. setacea. Foram avaliados o desenvolvimento da microenxertia, a ocorrência de brotações adventícias do porta-enxerto e o percentual de microenxertos com folhas expandidas. Os porta-enxertos foram submetidos à avaliação anatômica e histoquímica. $\mathrm{O}$ desenvolvimento dos microenxertos e o número de brotações adventícias foram maiores quando se utilizou porta-enxertos de $P$. edulis e menores com porta-enxertos de $P$. setacea e $P$. alata. Porta-enxertos de $P$. edulis, $P$. cincinnata, $P$. alata e $P$. setacea proporcionaram, respectivamente, 30,3,10,1,6 e $0 \%$ de microenxertos com folhas expandidas. As avaliações histológicas evidenciaram maior espessura da região cortical em porta-enxertos de P. edulis, enquanto em P. setacea foi observado menor número de camadas corticais, maior quantidade de fibras floemáticas e de alcaloides, características que influenciaram negativamente o resultado da microenxertia.
\end{abstract}

Termos para indexação: Passiflora, anatomia quantitativa, micropropagação, porta-enxertos silvestres.

\section{Ex vitro interspecific micrografting in passionflower}

\begin{abstract}
This study aimed at evaluating the effect of Passiflora species used as rootstocks on the success and development of ex vitro interspecific micrografting, and at anatomically characterizing the region where it is done. Stem apices of Passiflora edulis f. flavicarpa were grafted onto the hypocotyl of $P$. alata, P. cincinnata, $P$. edulis, and $P$. setacea seedlings. The micrografting development, the occurrence of adventitious shoots in rootstocks and the percentage of micrografts with expanded leaves were evaluated. The rootstocks were subjected to anatomical and histochemical evaluation. Micrograft development and adventitious shoot number were higher when $P$. edulis rootstocks were used, and lower for rootstocks of $P$. setacea and $P$. alata. P. edulis, $P$. cincinnata, $P$. alata, and $P$. setacea rootstocks developed $30.3,10,1.6$, and $0 \%$ of micrografts with expanded leaves, respectively. The histological evaluation revealed increased thickness of the cortical region in rootstocks of $P$. edulis, while in P. setacea a lower number of cortical layers, increased phloem fibers, and increased alkaloids were observed, characteristics that negatively influenced the micrografting outcome.
\end{abstract}

Index terms: Passiflora, quantitative anatomy, micropropagation, wild rootstocks.

\section{Introdução}

O Brasil é um dos centros de origem da família Passifloraceae, da qual várias espécies nativas têm potencial agronômico (Oliveira \& Ruggiero, 2005). O maracujazeiro-azedo (Passiflora edulis f. flavicarpa) é uma das principais plantas frutíferas brasileiras (Santos Filho et al., 2004; Oliveira \& Ruggiero, 2005), no entanto, seu cultivo tem sido prejudicado pela doença do endurecimento dos frutos, causada principalmente pelo Cowpea aphid-borne mosaic virus (CABMV), disseminada por todas as regiões produtoras (Nascimento et al., 2004). A enfermidade, que é transmitida principalmente por insetos, reduz a produtividade e a vida útil dos pomares e inviabiliza a comercialização dos frutos afetados (Santos Filho et al., 2004).

A microenxertia (Murashige et al., 1972) consiste em enxertar ápices caulinares de plantas com características de interesse em caules de porta-enxertos obtidos a partir de sementes, normalmente utilizando incisões na epiderme e em parte do córtex (Paz \& Pasqual, 1998). A técnica já foi empregada na eliminação de

Pesq. agropec. bras., Brasília, v.44, n.5, p.446-453, maio 2009 
vírus em citros (Navarro et al., 1975), em essências florestais (Navarro, 1988) e em abacateiro (Raharjo \& Litz, 2005), e apresenta a vantagem da superação do período de juvenilidade, que ocorre na propagação por semente. Ribeiro et al. (2008) utilizaram a microenxertia ex vitro visando à eliminação do vírus CABMV em maracujazeiro-azedo e obtiveram um percentual de sucesso de $32,5 \%$ na microenxertia, bem como a eliminação do vírus em $93 \%$ dos microenxertos analisados.

A microenxertia interespecífica é usualmente empregada em citros (Navarro, 1988; Oliveira et al., 2002), mas não foi descrita para passifloráceas. A técnica da enxertia interespecífica é utilizada em maracujazeiros e proporciona vantagens referentes à resistência a patógenos de solo, tais como Fusarium spp., conferida por porta-enxertos de $P$. cincinnata e $P$. setacea (Chaves et al., 2004; Silva et al., 2005).

A compatibilidade entre o enxerto e o porta-enxerto é fundamental para o sucesso da microenxertia, podendo estar relacionada a fatores anatômicos e fisiológicos (Navarro, 1988; Pio et al., 2001; Anselmini \& Zanette, 2008). Nesse sentido, a análise histológica pode proporcionar a caracterização das estruturas envolvidas na associação entre os tecidos e favorecer o entendimento dos resultados da microenxertia (Estrada-Luna et al., 2002). Outros fatores que podem interferir no resultado da microenxertia são a condição nutricional dos tecidos (Estrada-Luna et al., 2002) e a presença de compostos que possam prejudicar o desenvolvimento do microenxerto, como compostos fenólicos, cuja oxidação libera substâncias tóxicas (Paz \& Pasqual, 1998), ou alcaloides, que interferem no desenvolvimento de explantes in vitro (Latado et al., 2007).

Considerando os resultados positivos da enxertia interespecífica em passifloráceas (Chaves et al., 2004; Silva et al., 2005), estudos que possam evidenciar a eficácia da microenxertia interespecífica podem contribuir para a propagação e limpeza clonal do maracujazeiro-azedo. Dessa forma, o objetivo deste trabalho foi verificar o efeito de espécies de passifloráceas utilizadas como porta-enxerto no desenvolvimento do microenxerto e no pegamento da microenxertia ex vitro a partir de explantes de $P$. edulis f. flavicarpa, bem como a caracterização anatômica e histoquímica do caule dessas passifloráceas na região da microenxertia.

\section{Material e Métodos}

Os trabalhos foram realizados entre os meses de agosto de 2007 a junho de 2008, no Laboratório de Anatomia Vegetal e Micropropagação da Universidade Estadual de Montes Claros, MG. Foram utilizadas como matrizes plantas de $P$. edulis f. flavicarpa variedade Rubi Gigante com idade entre seis meses e um ano, mantidas em condições de viveiro, que apresentavam crescimento vigoroso e ausência de sintomas de ataque de pragas e doenças.

Os porta-enxertos foram obtidos a partir da germinação de sementes de $P$. alata, $P$. cincinnata, $P$. edulis f. Alavicarpa variedade Rubi Gigante e P. setacea. As sementes foram desinfestadas em solução de hipoclorito de sódio a $1 \%$ por 5 min e, em seguida, submetidas à tríplice lavagem em água destilada, por $3 \mathrm{~min}$. A semeadura foi realizada em recipientes de plástico com capacidade de $50 \mathrm{~mL}$, em substrato comercial Plantmax previamente esterilizado em estufa de secagem a $100^{\circ} \mathrm{C}$ por 24 horas. $\mathrm{O}$ acondicionamento foi feito em câmara com iluminação artificial ajustada para fotoperíodo de 16 horas de luz.

Foram utilizados porta-enxertos das quatro espécies com mesmo grau de desenvolvimento, com comprimento do hipocótilo entre 5 e $7 \mathrm{~cm}$, diâmetro do hipocótilo entre 1 e $2 \mathrm{~mm}$ e três ou quatro folhas (cotilédones mais uma ou duas folhas permanentes). Ápices caulinares com 0,2 a $0,4 \mathrm{~mm}$ de comprimento, constituídos pelo meristema apical com dois a quatro primórdios foliares, foram microenxertados em abertura retangular de aproximadamente $8 \times 5 \mathrm{~mm}$, realizada de modo a remover a epiderme e camadas celulares corticais na porção mediana do hipocótilo dos porta-enxertos, segundo metodologia desenvolvida por Ribeiro et al. (2008). As plantas microenxertadas foram cobertas por um saco de polietileno, para manutenção de alta umidade, e foram mantidas à temperatura ambiente em câmara com iluminação artificial ajustada para fotoperíodo de 16 horas. O experimento foi realizado em delineamento em blocos ao acaso com quatro tratamentos (espécies do porta-enxerto), seis repetições e dez microenxertias por parcela.

Aos 7, 14, 21 e 28 dias, foi avaliado o desenvolvimento da microenxertia segundo a escala de notas: 0 , microenxerto ausente; 1 , microenxerto necrosado sem calejamento; 2, microenxerto necrosado com calejamento; 3 , microenxerto clorótico sem desenvolvimento; 4, microenxerto verde sem 
desenvolvimento; 5, microenxerto com desenvolvimento de primórdios foliares; 6, microenxerto apresentando folha expandida. Nos mesmos períodos, foi avaliado o desenvolvimento de brotações adventícias do porta-enxerto, segundo a escala: 0 , porta-enxerto sem calejamento apical ou necrosado; 1 , ausência de gema no porta-enxerto; 2 , gema sem primórdios desenvolvidos no porta-enxerto; 3 , brotação com primórdios foliares no porta-enxerto; 4 , brotação com folha expandida no porta-enxerto. Após cada avaliação, as gemas ou brotações, quando presentes, foram excisadas para não comprometer o desenvolvimento do microenxerto. $\mathrm{O}$ pegamento dos microenxertos foi avaliado aos 28 dias. A presença de folha expandida foi considerada indicativo de pegamento da microenxertia.

Para as avaliações do efeito da espécie utilizada como porta-enxerto sobre o desenvolvimento da microenxertia e sobre a ocorrência de brotações adventícias no porta-enxerto, foi utilizado o teste não paramétrico de Kruskall-Wallis. Para a variável percentual de microenxertos com folhas expandidas, os dados foram convertidos em arc sen $(\mathrm{x} / 100)^{0,5} \mathrm{e}$ submetidos à análise de variância, e as médias foram comparadas pelo teste de Tukey, a $5 \%$ de probabilidade. As análises dos dados foram realizadas com uso do SAS (SAS Institute, 1990).

Para as avaliações anatômicas, foram realizadas secções transversais na região mediana do hipocótilo de porta-enxertos de cada uma das espécies, nas mesmas alturas em que as microenxertias foram realizadas. As secções foram coradas com azul de alcian e safranina, por 10 min em água, e montadas em lâminas de vidro com gelatina glicerinada. Foi avaliada a anatomia quantitativa utilizando 20 repetições por espécie. A partir da avaliação das secções, foram determinadas as camadas celulares da epiderme, córtex, fibras floemáticas, floema, xilema primário e secundário e medula. Os dados foram submetidos à análise de variância e, quando encontradas diferenças significativas entre as espécies pelo teste $F$, foi empregado o teste de Tukey, a 5\% de probabilidade, para a comparação de médias. A documentação fotográfica foi realizada utilizando uma câmera digital, modelo Evolution LC, acoplada a um microscópio óptico Olympus CX41.

Para as avaliações histoquímicas, foram feitas secções a mão livre em material fresco nas mesmas regiões onde foram realizadas as microenxertias.
As secções foram submetidas aos testes com reagente de Elran (Johansen, 1940), para a detecção de alcaloides (coloração castanho-avermelhada); cloreto férrico (Johansen, 1940), para a detecção de compostos fenólicos totais (coloração negra); Sudan IV (Foster, 1949), para a detecção de lipídios totais (coloração vermelha); lugol (Johansen, 1940), para a detecção de amido (coloração roxa) e azul mercúrio de bromofenol (Mazia et al., 1953), para a detecção de proteínas (coloração azul).

\section{Resultados e Discussão}

Os índices médios de desenvolvimento da microenxertia mostram que, em todos os tratamentos, ocorreram altas taxas de necrose dos ápices na fase inicial (Tabela 1). Os índices de desenvolvimento mais elevados foram 2,33 em P. alata, aos 7 dias, e 2,27 em P. setacea, aos 14 dias. Esses resultados representam maior tendência de calejamento dos porta-enxertos dessas espécies. Embora o calejamento no porta-enxerto seja considerado importante para a aderência do ápice e a junção inicial na microenxertia (Estrada-Luna et al., 2002; Ribeiro et al., 2008), Navarro et al. (1975) observaram, em citros, que o calejamento excessivo pode levar à absorção do ápice e ao impedimento de seu desenvolvimento. A diminuição dos índices de desenvolvimento em $P$. alata e $P$. setacea, nas últimas avaliações, está relacionada à tendência de morte dos microenxertos e ao pequeno desenvolvimento das microenxertias remanescentes nesses porta-enxertos.

A partir dos 21 dias, as microenxertias em porta-enxertos de $P$. edulis e $P$. cincinnata apresentaram maiores índices de desenvolvimento. Os índices de 4,61 aos 21 dias e 4,58 aos 28 dias em P. cincinnata indicam que os microenxertos estavam, em média, entre os estádios microenxerto verde sem desenvolvimento e microenxerto com desenvolvimento de primórdios foliares. Já em $P$. edulis, os índices de 4,90 aos 21 dias e 5,78 aos 28 dias indicam que a maioria dos microenxertos apresentava desenvolvimento de primórdios foliares. As avaliações dos índices de brotações adventícias do porta-enxerto evidenciaram diferenças entre os tratamentos a partir dos 14 dias. Os maiores índices foram verificados em portaenxertos de $P$. edulis - 1,5 aos 21 dias e 1,0 aos 28 dias - e os menores em $P$. setacea $-0,72$ aos 21 dias e 0,33 aos 28 dias - e P. alata-0,71 aos 21 dias e 0,33 
aos 28 dias (Tabela 1). Embora os índices observados em todas as avaliações indiquem ausência ou pequeno desenvolvimento das brotações, é importante ressaltar que houve excisão das gemas ou brotações, quando presentes, após cada avaliação. As brotações adventícias do porta-enxerto são indesejáveis e normalmente prejudicam o desenvolvimento do ápice (Navarro et al., 1975; Ribeiro et al., 2008), embora sejam indicativas da capacidade de organogênese dos tecidos. Como o sucesso da microenxertia depende da capacidade de regeneração de tecidos e de desenvolvimento da conexão vascular entre ápice e porta-enxerto (Estrada-Luna et al., 2002; Kawaguchi et al., 2008), é possível que a menor capacidade de organogênese em porta-enxertos de $P$. setacea e $P$. alata seja um dos fatores relacionados ao menor desenvolvimento dos microenxertos.

Verificou-se influência da espécie do porta-enxerto sobre o percentual de microenxertos com folhas expandidas $(\mathrm{p}<0,0001)$, consideradas como indicativo de pegamento da microenxertia (Figura 1). Os melhores resultados foram obtidos com porta-enxertos de P. edulis. Quando a microenxertia foi realizada em $P$. cincinnata, os resultados obtidos foram intermediários. Os menores percentuais de pegamento foram observados nas microenxertias realizadas em $P$. alata, que apresentou 1,6\% de microenxertos com folha expandida, e em $P$. setacea, em que não houve pegamento.
Os resultados das avaliações anatômicas indicaram maiores diferenças estruturais entre os porta-enxertos de $P$. setacea e $P$. edulis, espécies que proporcionaram resultados opostos em relação ao pegamento da microenxertia, enquanto $P$. edulis e $P$. cincinnata, que proporcionaram melhores resultados, apresentaram características anatômicas semelhantes. Todas as espécies apresentam epiderme unisseriada (Figura 2). Plântulas de $P$. edulis apresentaram maior espessura cortical e plântulas de $P$. setacea, menor espessura (Tabela 2 e Figura 2). A estrutura da região cortical é importante para o sucesso da microenxertia, uma vez que é nessa região que o ápice é inserido (Navarro et al., 1975; Ribeiro et al., 2008). Segundo Estrada-Luna et al. (2002), as células parenquimáticas corticais estão envolvidas no calejamento e no estabelecimento da conexão vascular entre ápice e porta-enxerto. Areduzida espessura do córtex nos porta-enxertos de $P$. setacea dificulta a execução da técnica da microenxertia e pode contribuir para danificar o sistema vascular. Chaves et al. (2004) relataram que a enxertia convencional, em porta-enxertos de $P$. setacea, proporciona menor sucesso em razão da pequena espessura do caule das plântulas, e sugerem ser necessário o uso de porta-enxertos com maior desenvolvimento caulinar.

Plântulas de $P$. setacea tiveram maior número de fibras floemáticas. Essas células não foram observadas em P. edulis (Tabela 2 e Figura 2). Em P. setacea, em razão do elevado grau de esclerificação, pode ter havido

Tabela 1. Índices de desenvolvimento do microenxerto e brotações adventícias em porta-enxertos de Passiflora alata, P. cincinnata, $P$. edulis e $P$. setacea aos 7, 14, 21 e 28 dias.

\begin{tabular}{|c|c|c|c|c|c|}
\hline \multirow[t]{2}{*}{ Parâmetro } & \multirow[t]{2}{*}{ Porta-enxerto } & \multicolumn{4}{|c|}{ Tempo (dias) } \\
\hline & & 7 & 14 & 21 & 28 \\
\hline \multirow{5}{*}{ Desenvolvimento do microenxerto ${ }^{(1)}$} & P. alata & 2,33 & 0,83 & 2,63 & 1,72 \\
\hline & P. cincinnata & 1,05 & 1,32 & 4,61 & 4,58 \\
\hline & P. edulis & 0,98 & 1,62 & 4,90 & 5,78 \\
\hline & P. setacea & 0,93 & 2,27 & 2,28 & 1,00 \\
\hline & $\mathrm{p}^{(2)}$ & 0,024 & $<0,0001$ & 0,0034 & $<0,0001$ \\
\hline \multirow[t]{5}{*}{ Brotação adventícia do porta-enxerto $^{(3)}$} & P. alata & 0,94 & 0,83 & 0,71 & 0,33 \\
\hline & P. cincinnata & 1,05 & 1,21 & 1,00 & 0,83 \\
\hline & P. edulis & 1,01 & 1,38 & 1,50 & 1,00 \\
\hline & P. setacea & 0,95 & 0,91 & 0,72 & 0,33 \\
\hline & $\mathrm{p}$ & 0,83 & 0,0495 & 0,0035 & 0,018 \\
\hline
\end{tabular}

${ }^{(1)}$ Escala de notas utilizadas na avaliação: 0 , microenxerto ausente; 1 , microenxerto necrosado sem calejamento; 2 , microenxerto necrosado com calejamento; 3, microenxerto clorótico sem desenvolvimento; 4, microenxerto verde sem desenvolvimento; 5 , microenxerto com desenvolvimento de primórdios foliares; 6, microenxerto com folhas expandidas. ${ }^{(2)}$ Nível de significância do teste de Kruskall-Wallis; quando menor que 0,05 , indica diferenças significativas a $5 \%$ de probabilidade entre as médias na coluna. ${ }^{(3)}$ Escala de notas utilizadas na avaliação: 0 , porta-enxerto sem calejamento apical ou necrosado; 1 , ausência de gema no porta-enxerto; 2, gema sem primórdios desenvolvidos no porta-enxerto; 3, brotação com primórdios foliares no porta-enxerto; 4, brotação com folha expandida no porta-enxerto. 


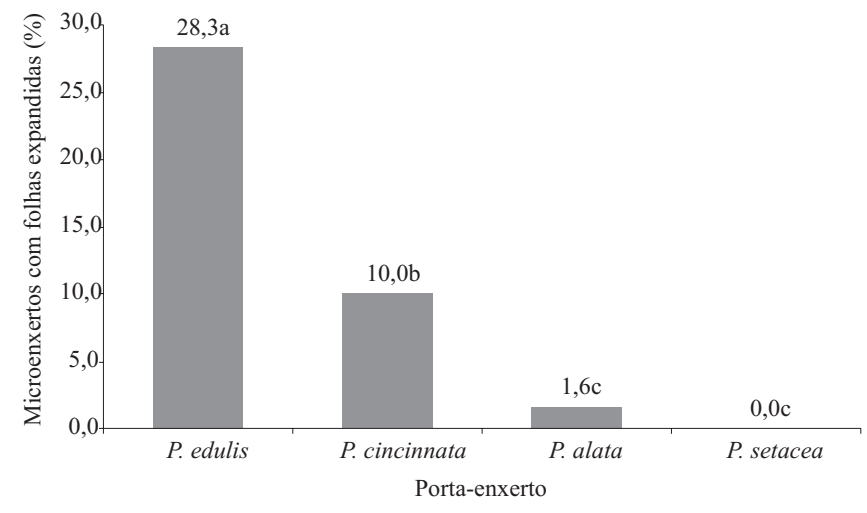

Figura 1.Efeito da espécie do porta-enxerto sobre o percentual de microenxertos de P. edulis com folhas expandidas. Letras iguais indicam ausência de diferença entre os tratamentos pelo teste de Tukey, a 5\% de probabilidade.

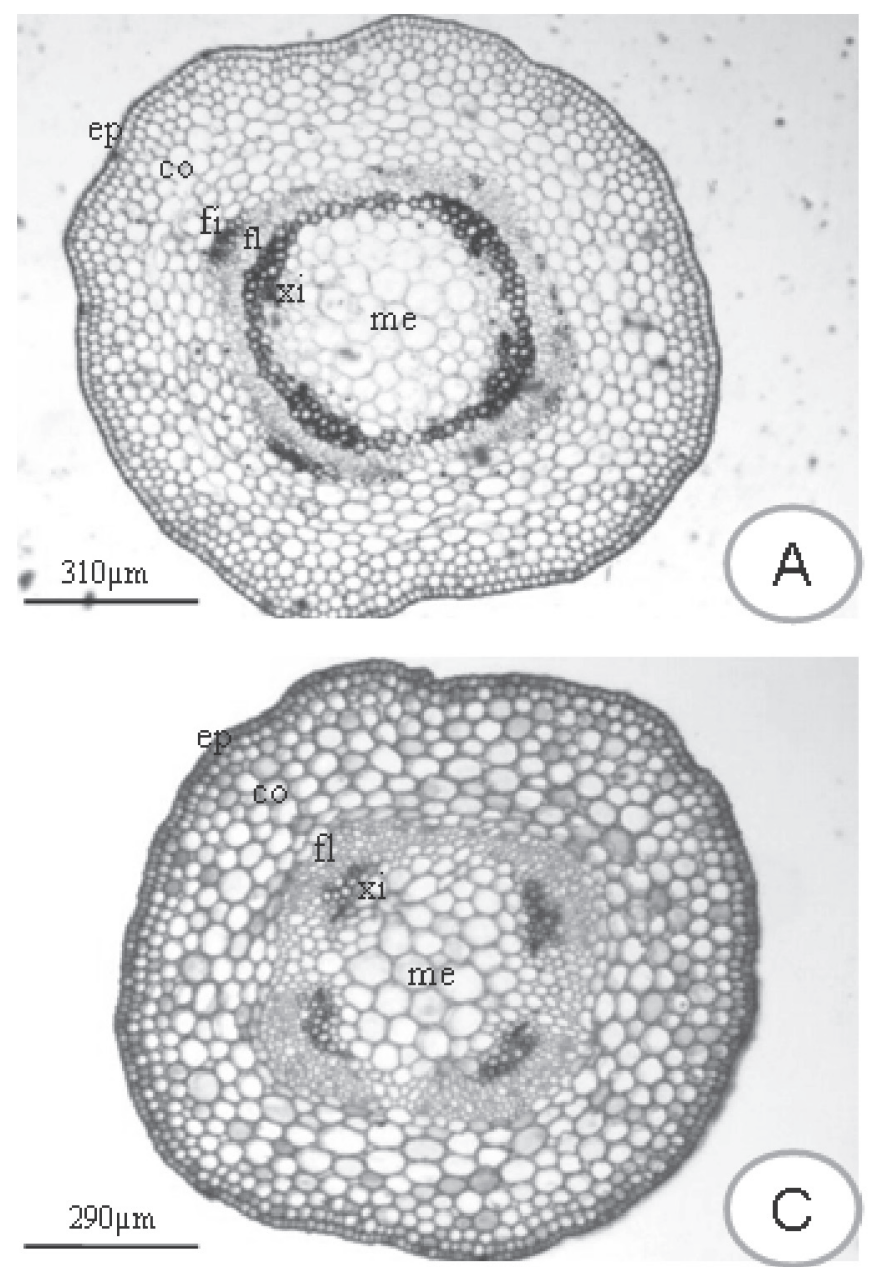

restrição do transporte de substâncias e estabelecimento da conexão vascular entre microenxerto e porta-enxerto, o que contribuiu para o insucesso da microenxertia. Kawaguchi et al. (2008) afirmam que é possível evidenciar, na microenxertia, a incompatibilidade entre espéciesde solanáceaspormeio daavaliaçãohistológica, e que essa incompatibilidade está associada à ausência de conexão vascular, o que impede a translocação de fotoassimilados, minerais e água do porta-enxerto para o ápice. Mayer et al. (2006) observaram, em trabalhos realizados com enraizamento de videira (Vitis sp.), que a ocorrência de fibras no floema secundário e a presença de calotas de fibras do floema primário estabelecem limitações à organogênese. Na enxertia convencional interespecífica utilizando enxertos de

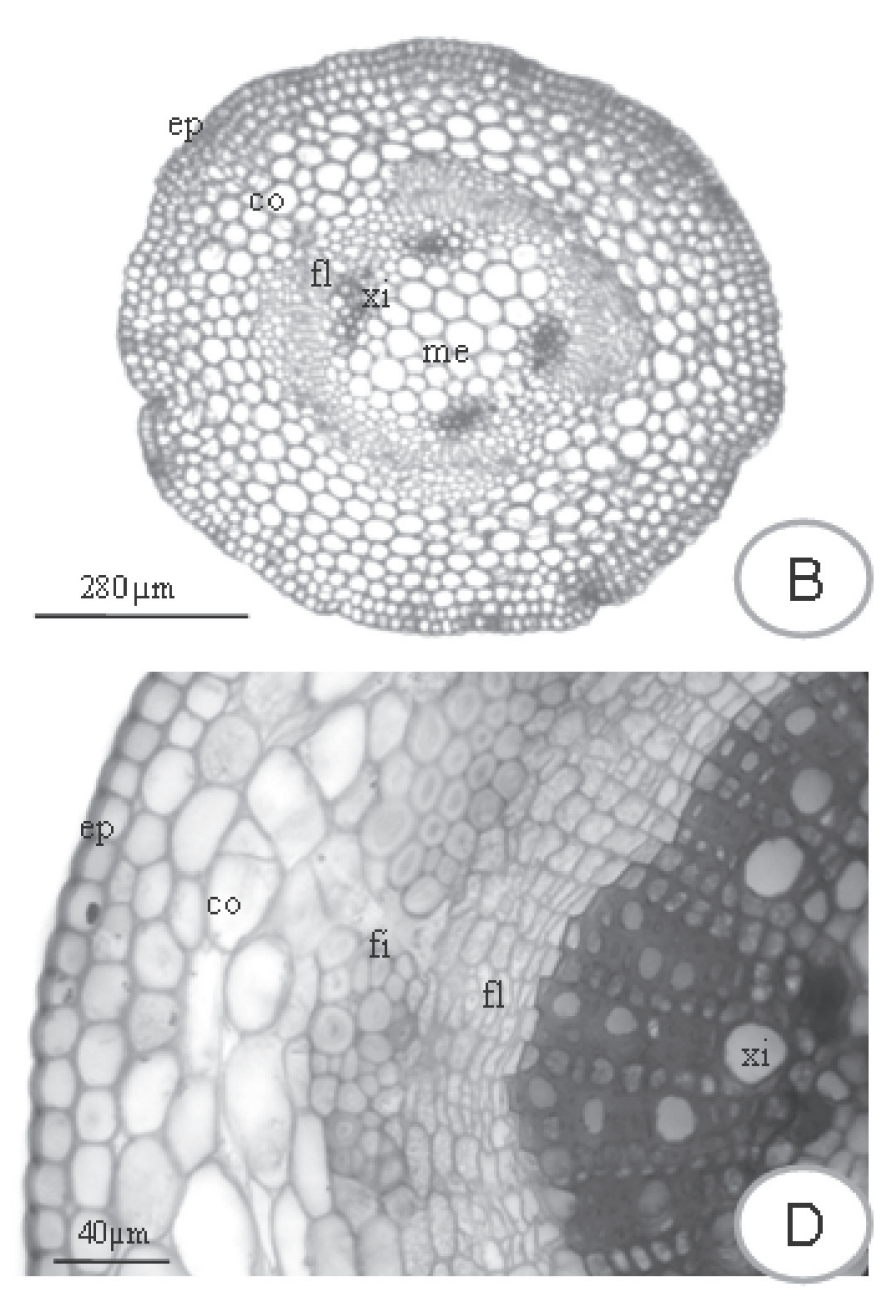

Figura 2. Avaliações anatômicas na região do hipocótilo em Passiflora alata (A), P. edulis (B), P. cincinnata (C) e P. setacea (D). co, córtex; ep, epiderme; fi, fibras; fl, floema; me, medula; xi, xilema. 
P. edulis, Nogueira Filho et al. (2005) obtiveram pegamento de 100 e $30,6 \%$, respectivamente, quando utilizaram porta-enxertos de $P$. cincinnata e $P$. setacea, o que ressalta a menor propensão da última espécie ao uso como porta-enxerto.

O número de camadas de células do floema não apresentou diferenças entre as espécies estudadas (Tabela 2). Plântulas de $P$. alata apresentaram maior número de camadas celulares no xilema primário e menor número de células no xilema secundário, o que evidencia menor grau de diferenciação em relação às outras espécies. $\mathrm{O}$ contrário foi observado em porta-enxertos de $P$. setacea. O baixo grau de desenvolvimento secundário é a principal diferença anatômica entre porta-enxertos de $P$. alata e de $P$. edulis. Esta condição pode ter afetado o resultado da microenxertia, uma vez que o desenvolvimento secundário das plântulas é favorável a essa técnica por estar relacionado à maior atividade do câmbio vascular e à maior capacidade de translocação. Silva et al. (2005) verificaram um desenvolvimento de $96,8 \%$ dos enxertos na enxertia convencional de $P$. edulis em porta-enxertos de $P$. alata, o que evidencia a ausência de incompatibilidade genética.

Não foram constatadas diferenças significativas no que se refere ao número de células no maior diâmetro da medula (Tabela 2). Os testes histoquímicos indicaram a presença de lipídios totais na cutícula de todas as espécies. No entanto, em P. edulis, sua presença foi menos evidente que nas demais espécies. Foram encontradas evidências da presença de amido nas regiões do córtex e medula, em todas as espécies. Reservas proteicas não foram detectadas nas espécies, em nenhum dos tecidos observados. A condição nutricional dos tecidos envolvidos na microenxertia é determinante para o resultado, pois nas fases iniciais não existe conexão vascular entre as partes. Assim, na ausência de translocação de água, minerais e substâncias orgânicas via floema e xilema, o microenxerto depende de suas reservas e de reservas dos tecidos do porta-enxerto adjacentes à região da microenxertia (Richardson et al., 1996). No presente trabalho, no entanto, não foi possível observar diferenças significativas entre as espécies em relação às reservas nutritivas.

Em relação a compostos secundários, não foram detectados fenólicos gerais em nenhuma das espécies estudadas. Foi constatada a presença de alcaloides no córtex e medula de $P$. alata, $P$. cincinnata e $P$. setacea e no córtex de $P$. edulis, com maior abundância em $P$. setacea (Tabela 3 ). É comum a ocorrência de alcaloides em espécies de Passiflora (Barbosa, 2006; Villas Bôas, 2007). Esses compostos, comumente associados à defesa contra patógenos e herbívoros, apresentam citotoxicidade e capacidade de deterrência (Taiz \& Zeiger, 2004). Não são encontradas, na literatura, referências sobre a influência direta de alcaloides no pegamento da microenxertia. Por outro lado, a síntese de compostos secundários está relacionada à diferenciação e especialização das células (Evert, 2006). Como a capacidade de divisão celular e a competência para a organogênese são correlacionadas negativamente com a diferenciação (Taiz \& Zeiger, 2004; Gahan \& George, 2008), a maior abundância de alcaloides no córtex de $P$. setacea em relação às outras espécies é outro indicativo de sua menor capacidade de desenvolvimento da conexão vascular entre ápice e porta-enxerto.

A ausência de pegamento na microenxertia em P. setacea, associada às dificuldades na obtenção de porta-enxertos cultivados a partir de sementes (Nogueira Filho et al., 2005; Lima et al., 2006), é indicativo da inviabilidade do uso dessa espécie como porta-enxerto na microenxertia ex vitro. Apesar do baixo nível de pegamento na microenxertia em $P$. alata, é possível que sejam alcançados melhores resultados com a utilização de porta-enxertos com maior grau de desenvolvimento, uma vez que a enxertia convencional mostrou-se viável (Silva et al., 2005) e não existem diferenças anatômicas importantes em relação a $P$. edulis. Considerando-se os

Tabela 2. Número médio de camadas celulares do córtex, fibras, floema, xilema primário, xilema secundário e medula do hipocótilo em porta-enxertos de Passiflora alata, . cincinnata, . edulis e P. setacea ${ }^{(1)}$.

\begin{tabular}{lcccccc}
\hline Porta-enxerto & Córtex & Fibras & Floema & Xilema primário & Xilema secundário & Medula \\
\hline$P$. alata & $8,00 \mathrm{~b}$ & $1,40 \mathrm{c}$ & $5,20 \mathrm{a}$ & $3,75 \mathrm{a}$ & $1,15 \mathrm{c}$ & $9,95 \mathrm{a}$ \\
$P$. cincinnata & $7,20 \mathrm{c}$ & $3,20 \mathrm{~b}$ & $4,40 \mathrm{a}$ & $2,85 \mathrm{ab}$ & $2,45 \mathrm{~b}$ & $9,15 \mathrm{a}$ \\
$P$. edulis & $8,60 \mathrm{a}$ & $0,00 \mathrm{~d}$ & $4,75 \mathrm{a}$ & $3,05 \mathrm{ab}$ & $2,55 \mathrm{~b}$ & $9,70 \mathrm{a}$ \\
$P$. setacea & $4,30 \mathrm{~d}$ & $4,20 \mathrm{a}$ & $5,00 \mathrm{a}$ & $2,70 \mathrm{~b}$ & $5,45 \mathrm{a}$ & $10,69 \mathrm{a}$ \\
\hline CV $(\%)$ & 9,91 & 46,29 & 21,17 & 24,86 & 31,49 & 17,93 \\
\hline
\end{tabular}

${ }^{(1)}$ Médias seguidas por letras iguais nas colunas indicam ausência de diferenças entre as espécies pelo teste de Tukey, a 5\% de probabilidade. 
Tabela 3. Avaliações histoquímicas de alcaloides, fenóis totais, lipídios totais, amido e proteínas na cutícula, córtex, sistema vascular e medula de plântulas de Passiflora alata, P. cincinnata, P. edulis e P. setacea.

\begin{tabular}{|c|c|c|c|c|}
\hline \multirow[t]{2}{*}{ Espécie } & \multicolumn{4}{|c|}{ Local } \\
\hline & Cutícula & Córtex & Sistema vascular & Medula \\
\hline & \multicolumn{4}{|c|}{ Alcaloides (reagente de Elran) } \\
\hline P. alata & - & + & - & + \\
\hline P. cincinnata & - & + & - & + \\
\hline P. edulis & - & + & - & - \\
\hline \multirow[t]{2}{*}{ P. setacea } & - & +++ & - & +++ \\
\hline & \multicolumn{4}{|c|}{ Fenóis totais (cloreto férrico) } \\
\hline P. alata & - & - & - & - \\
\hline P. cincinnata & - & - & - & - \\
\hline P. edulis & - & - & - & - \\
\hline \multirow[t]{2}{*}{ P. setacea } & - & - & - & - \\
\hline & \multicolumn{4}{|c|}{ Lipídios totais (Sudan IV) } \\
\hline P. alata & + & - & - & - \\
\hline P. cincinnata & + & - & - & - \\
\hline P. edulis & + & - & - & - \\
\hline \multirow[t]{2}{*}{ P. setacea } & + & - & - & - \\
\hline & \multicolumn{4}{|c|}{ Amido (lugol) } \\
\hline P. alata & - & + & - & + \\
\hline P. cincinnata & - & + & - & + \\
\hline P. edulis & - & + & - & + \\
\hline \multirow[t]{2}{*}{ P. setacea } & - & + & - & + \\
\hline & \multicolumn{4}{|c|}{ Proteínas (azul de bromofenol) } \\
\hline P. alata & - & - & - & - \\
\hline P. cincinnata & - & - & - & - \\
\hline P. edulis & - & - & - & - \\
\hline P. setacea & - & - & - & - \\
\hline
\end{tabular}

resultados obtidos no presente trabalho e na enxertia convencional de $P$. edulis em $P$. cincinnata (Nogueira Filho et al., 2005), é possível observar que existe boa perspectiva de sua utilização como porta-enxerto na microenxertia interespecífica.

\section{Conclusões}

1. A utilização de porta-enxertos de $P$. edulis proporciona maior desenvolvimento da microenxertia, maior índice de brotações adventícias e maior percentual de microenxertos com folhas expandidas.

2. Nas microenxertias em porta-enxertos de $P$. alata e $P$. setacea, ocorre menor desenvolvimento e menor índice de brotações adventícias e a utilização de porta-enxertos de $P$. setacea não proporciona microenxertos com folhas expandidas.

3. Plântulas de $P$. setacea apresentam menor espessura cortical, maior grau de esclerificação e maior concentração de alcaloides, o que influencia negativamente o resultado da microenxertia.

\section{Agradecimentos}

À Fundação de Amparo à Pesquisa do Estado de Minas Gerais, pela concessão de bolsas; ao Professor Sérgio Avelino Mota Nobre, coordenador do Laboratório de Ecologia e Biocontrole de Microorganismos da Universidade Estadual de Montes Claros, pela disponibilização de equipamentos.

\section{Referências}

ANSELMINI, J.I.; ZANETTE, F. Microenxertia e sua caracterização morfológica em Araucaria angustifolia. Ciência Rural, v.38, p.967-973, 2008.

BARBOSA, P.R. Estudo da ação psicofarmacológica de extratos de Passiflora alata Dryander e Passiflora edulis Sims. 2006. 68p. Dissertação (Mestrado) - Universidade do Extremo Sul Catarinense, Criciúma.

CHAVES, R. da C.; JUNQUEIRA, N.T.V.; MANICA, I.; PEIXOTO, J.R.; PEREIRA, A.V.; FIALHO, J. de F. Enxertia de maracujazeiro-azedo em estacas herbáceas enraizadas de espécies de passifloras nativas. Revista Brasileira de Fruticultura, v.26, p.120-123, 2004.

ESTRADA-LUNA, A.A.; LÓPEZ-PERALTA, C.; CÁRDENAS-SORIANO, E. In vitro micrografting and the histology of graft union formation of selected species of prickly pear cactus (Opuntia spp.). Scientia Horticulturae, v.92, p.317-327, 2002.

EVERT, R.F. Esau's plant anatomy: meristems, cells, and tissues of the plant body: their structure, function, and development. $3^{\text {rd }}$ ed. Hoboken: John Wiley \& Sons, 2006, 601p.

FOSTER, A.S. Practical plant anatomy. 2.ed. Princeton: Van Nostrand, 1949.

GAHAN, P.B.; GEORGE, E.F. Adventitious regeneration. In: GEORGE, E.F.; HALL, M.A.; KLERK, G. (Ed.). Plant propagation by tissue culture. 3.ed. Dordrecht: Springer, 2008. p.355-402.

JOHANSEN, D.A. Plant microtechnique. New York: McGraw-Hill Book Company, 1940. 523p.

KAWAGUCHI, M.; TAJI, A.; BACKHOUSE, D.; ODA, M. Anatomy and physiology of graft incompatibility in solanaceous plants. The Journal of Horticultural Science \& Biotechnology, v.83, p.581-588, 2008.

LATADO, R.R.; CRISTOFANI-YALI, M.; CARVALHO, C.R. de; MACHADO, M.A.; Plantas autotetraplóides de citrus sob tratamento in vitro com colchicina. Pesquisa Agropecuária Brasileira, v.42, p.1429-1435, 2007.

LIMA, A. de A.; CALDAS, R.C.; SANTOS, V. da S. Germinação e crescimento de espécies de maracujá. Revista Brasileira de Fruticultura, v.28, p.125-127, 2006.

MAYER, J.L.S.; BIASI, L.A.; BONA, C. Capacidade de enraizamento de estacas de quatro cultivares de Vitis L. (Vitaceae) relacionada com os aspectos anatômicos. Acta Botânica Brasilica, v.20, p.563-568, 2006. 
MAZIA, D.; BREWER, P.A.; ALFERT, M. The cytochemical staining and measurement of protein with mercuric bromophenol blue. Biological Bulletin, v.104, p.57-67, 1953.

MURASHIGE, T.; BITTERS, W.P.; RANGAN, T.S.; NAUER, E.M.; ROISTACHER, C.N.; HOLLIDAY, P.B. A technique of shoot apex grafting and its utilization towards recovering virus-free Citrus clones. HortScience, v.7, p.118-119, 1972.

NASCIMENTO, A.V.S.; SOUZA, A.R.R.; ALFENAS, P.F.; ANDRADE, G.P.; CARVALHO, M.G.; PIO-RIBEIRO, G.; ZERBINI, M. Análise filogenética de Potyvírus causando endurecimento dos frutos do maracujazeiro no Nordeste do Brasil. Fitopatologia Brasileira, v.29, p.378-383, 2004.

NAVARRO, L. Application of shoot-tip grafting in vitro to woody species. Acta Horticulturae, v.227, p.43-55, 1988.

NAVARRO, L.; ROISTACHER, C.N.; MURASHIGE, T. Improvement of shoot-tip grafting in vitro for virus-free citrus. Journal of the American Society for Horticultural Science, v.100, p.471-479, 1975.

NOGUEIRA FILHO, G.C.; RONCATTO, G.; RUGGIERO, C.; OLIVEIRA, J.C. de; MALHEIROS, E.B. Propagação vegetativa do maracujazeiro-conquista de novas adesões. In: FALEIRO, F.G.; JUNQUEIRA, N.T.V.; BRAGA, M.F. (Ed.). Maracujá: germoplasma e melhoramento genético. Planaltina: Embrapa Cerrados, 2005. p.339-358.

OLIVEIRA, I.V. de M.; DAMIÃO FILHO, C.F.; CARVALHO, S.A. de. Enxertia em citrus por substituição de ápice caulinar. Revista Brasileira de Fruticultura, v.24, p.744-747, 2002.

OLIVEIRA, J.C.; RUGGIERO, C. Espécies de maracujá com potencial agronômico. In: FALEIRO, F.G.; JUNQUEIRA, N.T.V.; BRAGA, M.F. (Ed.). Maracujá: germoplasma e melhoramento genético. Planaltina: Embrapa Cerrados, 2005. p.141-158.

PAZ, O.P. da; PASQUAL, M. Microenxertia. In: TORRES, A.C.; CALDAS, L.S.; BUSO, J.A. Cultura de tecidos e transformação genética de plantas. Brasília: Embrapa-SPI; Embrapa-CNPH, 1998. v.1. p.147-159.

PIO, R.; CASTRO, E.M. de; RAMOS, J.D.; GAVILANES, M.L.; RIBEIRO, W.G. Características anatômicas de porta-enxertos para microenxertia em diferentes alturas. Ciência e Agrotecnologia, V.25, p.848-852, 2001.

RAHARJO, S.H.T.; LITZ, R.E. Micrografting and ex vitro grafting for somatic embryo rescue and plant recovery in avocado (Persea americana). Plant Cell, Tissue and Organ Culture, v.82, p.1-9, 2005.

RIBEIRO, L.M.; PEIXOTO, J.R.; ANDRADE, S.R.M. de; FONSECA, R.S.; VIEIRA, L.M.; PEREIRA, W.V.S. Microenxertia ex vitro para eliminação do vírus CABMV em maracujá-azedo. Pesquisa Agropecuária Brasileira, v.43, p.589-594, 2008.

RICHARDSON, F.V.M.; SAOIR, S.M.; HARVEY, B.M.R. A study of the graft union in in vitro micrografted apple. Plant Growth Regulation, v.20, p.17-23, 1996.

SANTOS FILHO, H.P.; LARANJEIRA, F.F.; SANTOS, C.C.F. dos; BARBOSA, C. de J. Doenças do maracujazeiro. In: LIMA, A. de A.; CUNHA, M.A.P. da. (Ed.). Maracujá: produção e qualidade na passicultura. Cruz das Almas: Embrapa Mandioca e Fruticultura, 2004. p.241-280

SAS INSTITUTE. SAS user's guide: statistics version. Cary: SAS Institute, $1990.846 \mathrm{p}$.

SILVA, F.M.; CORRÊA, L. de S.; BOLIANI, A.C.; SANTOS, P.C. dos. Enxertia de mesa de Passiflora edulis Sims. f. flavicarpa Deg. sobre Passiflora alata Curtis, em ambiente de nebulização intermitente. Revista Brasileira de Fruticultura, v.27, p.98-101, 2005.

TAIZ, L.; ZEIGER, E. Fisiologia vegetal. Porto Alegre: Artmed, 2004. 719p.

VILLAS BÔAS, L. de B. Estudo dos constituintes químicos ansiolíticos e sedativos de Passiflora actinia Hook. 2007. 102p. Dissertação (Mestrado) - Universidade Federal do Paraná, Curitiba.

Recebido em 10 de fevereiro de 2009 e aprovado em 11 de maio de 2009 